\title{
Vzdělávací obsah: ukazují Bernsteinova teorie a sociální realismus cestu z krize? ${ }^{1}$
}

\section{Dominik Dvořák}

\begin{abstract}
Abstrakt: Teoretická studie poukazuje na dvě okolnosti, které limituji kvalitu obsahu vzdéláváni: jde o absenci teorie vèdèni a o problémy s predáváním konceptuálně náročného kurikula části sociokulturně znevýhodněných žákư. Při prekonáváni obou problémů může být užitečné pozdni sociologické dílo Basila Bernsteina, jehož vybrané a u nás méně známé myšlenky jsou v článku načrtnuty. Dále je ukázáno, jak na tyto koncepty navazuje tzv. sociálni realismus v pojetí M. Younga a skupiny Bernsteinových žáků. Jsou popsány dva modely kurikula, které vycházeji mj. z pojetí védèni jako systému vs. procesu. Nakonec je charakterizován smišený model výuky, který kombinuje prvky tradični a progresivni pedagogiky a predstavuje slibnou cestu pro predáváni konceptuálnè náročného kurikula širokému spektru žákü.
\end{abstract}

Klíčová slova: kurikulum, vzdělávaci obsah, sociologie vzdělávání, sociálni realismus.

„Existují dva druhy pošetilců: Jedni říkají, že vše, co je staré, je dobré, druzí tvrdí, že to, co je nové, je lepší. Jejich svár je stejně starý jako lidstvo samo, nicméně exponenciální rozvoj technologií tuto propast ještě prohloubil a spor vyostřil.“

Paul Saffo

Nespokojenost $s$ kvalitou vzdělávacího obsahu, který je vymezován $\mathrm{v}$ kurikulárních dokumentech a předáván ve výuce, se zdaleka neomezuje jen na české prostředí (Janík \& Slavík, 2009), ale známe ji z mnoha vyspělých zemí. Zahraniční autoři někdy klesající intelektuální náročnost výuky připisují tlaku testování, politice akontability apod. (Rizvi \& Lingard, 2009, s. 100); v České republice jsme však tyto mechanismy donedávna prakticky neznali - plošné testy se neujaly, kurikulární rámec dává školám široký prostor. Př́íciny krize vzdělávacího obsahu podle mne musíme hledat také jinde. Poukazujeme-li na problémy učiva ve vzdělávací praxi, nemůžeme přehlédnout krizi teorie vzdělávacího obsahu v pedagogice a př́buzných vědách. Čím víc se mluví o společnosti vědění či o znalostní ekonomice, tím více postrádáme relevantní porozumění místu znalostí ve vzdělávání (Maton \& Moore, 2009). Druhou stranou mince je to, že snahy o zvýšení konceptuální náročnosti

\footnotetext{
1 Text je výstupem grantu GA ČR Nadnárodní trendy v kurikulu školního vzdělávání a jejich působení v národním vzdělávacím systému (15-25137S).
} 
výuky v praxi zvyšují neúspěšnost žáků, zejména těch, kteři přicházejí do školy se sociokulturním znevýhodněním.

Proto v posledních letech budí velký zájem sociálni realismus, který nabízí teorii znalostí, resp. jejich předávání ve škole, a na jejím základě volá po rehabilitaci vzdělávacího obsahu. Staví se proti přesvědčení, že akademické znalosti jsou „doménou konzervativních sil ve vzděláváni", ale naopak předpokládá, že důraz na znalosti (zejména jejich pojmovou strukturu) je progresivní cestou podporující demokracii a sociální spravedlivost ve školství (Rata, 2016). Proto se pokouším stručně shrnout východiska a vybrané závěry sociálního realismu zejména v pojetí žáků Basila Bernsteina. Nejsem ovšem první, kdo v českém prostředís těmito myšlenkami pracuje (viz Štech, 2009, 2013; Kadlec, 2012; Knecht, 2014a aj.). Realistická pozice je navíc trvalou součástí evropské myšlenkové tradice a dnes vidíme obnovený zájem o realismus od filozofie po umění; jeho příciny zřejmě leží jak uvnitř jednotlivých oborů, tak v širší společenské situaci a potřebách lidí. V tomto textu jsem nemohl postihnout tyto širší souvislosti, zájemce odkazuji např. na knihu editovanou Matonem a Moorem (2010). ${ }^{2}$

\section{PozděJŠí Bernstein}

Zatímco u nás je problém „obsahového vyprazdňování " předkládán jako otázka kvality školství jako celku, v zahraničí je chápán zejména jako problém sociální spravedlivosti, nebot' $s$ méně kvalitním kurikulem se setkávají častěji žáci ze znevýhodněného prostředí (např. Perry \& Lamb, 2016), a tím se reprodukuje sociální nerovnost. Proto se role znalostí v kurikulu stala klíčovým tématem sociologie vzdělávání. Zásadní roli v tom sehráli badatelé ovlivnění dílem $B$. Bernsteina.

Britský sociolog Basil Bernstein (1924-2000) celý svůj odborný život věnoval studiu překážek bránících sociálnímu vzestupu a možnostem jejich překonání (Sadovnik, 2001). Nezůstal jen na poli tradiční sociologie, ale dotkl se mnoha otázek od kognice po didaktiku (Bulle, 2008) a propojoval tak analýzy na úrovních sociálního systému, uspořádání jednotlivých institucí, pravidel interakcí ve tř́dě i intrapsychických procesů. Je znám zejména svými sociolingvistickými pracemi z počátku šedesátých let minulého století, které do české pedagogiky uvedl J. Průcha a jsou dnes součástí základních učebnic oboru.

Od sedmdesátých let Bernstein (1990/2003, 1996/2000) myšlenku kódů, ${ }^{3}$ původně préedstavujících spojnici mezi uspořádáním společnosti a strukturními aspekty komunikace, zobecňoval na teorii pedagogických procesů, obsahů a nakonec i vědních oborů, jež jsou zdrojem učiva. Kódy poskytují odpověd' na základní otáz$\mathrm{ku}$, jak príslušnost jedince $\mathrm{k}$ určité trrídě ovlivňuje jeho poznávání a učení a jak tím dochází $\mathrm{k}$ reprodukci nerovností ve společnosti. Tyto pozdější práce u nás - jen s vý-

\footnotetext{
2 Děkuji zde editorům tohoto čísla a oběma recenzentům textu, kteří mě na četné přesahy popisované tematiky upozornili. Bohužel jsem jejich náměty dokázal promítnout do textu jen v omezené míre.

3 Nabízí se paralela např. s myšlenkami J. Piageta a, jak uvidíme dále, zejména L. S. Vygotského.
} 
jimkou textů S. Štecha (2009) - mají podstatně menší ohlas. Ovšem o Bernsteina byl po určité období malý zájem i v samém Spojeném království, kde působil na londýnském Institute of Education. Svou roli v tom hrála i složitost Bernsteinova vyjadřování. Kromě toho se zdála nepřijatelnou interpretace (kterou však on sám odmítal), že kódy užívané nižšími třídami jsou nejen jiné, ale také horší, popř. že žáci z dělnických rodin mají ve srovnání se středostavovskými dětmi určitý kognitivní deficit. $\mathrm{V}$ posledních letech však vidíme právě díky sociálním realistům velkou renezanci zájmu o Bernsteinovy myšlenky. Zde vyložíme jen malou část z nich.

Sociologie vědění i sociologie edukace se tradičně ptají, jak organizace poznání a způsoby jeho předávání souvisejí se strukturou společnosti (Hubík, 1999). Bernstein ve svých odpovědích vychází $\mathrm{z}$ více autorů, ale zásadní je pro něj Émile Durkheim (1858-1917). Přebírá jednak jeho realistické stanovisko (proti konstruktivismu), jednak myšlenku hierarchie typů vědění: každá společnost si kromě profánního/praktického vytváŕí i „posvátné" vědění, které souvisí $s$ dělbou práce, je abstraktní až ezoterické, ale současně potencující, nebot umožňuje uvažovat o alternativách budoucnosti. ${ }^{4} \mathrm{~V}$ současném světě od náboženství úlohu nositele posvátného vědění převzala věda. Zatímco mezi náboženstvím a vědou tak existuje kontinuita, naopak abstraktní vědecké a každodenní vědění jsou principiálně odděleny (např. Durkheim, 1912/2002; 1893/2004). V Bernsteinově koncepci proto hrají důležitou roli hranice mezi různými typy vědění: jde o rozlišení horizontálního (silně kontextově vázaného) a vertikálního (na kontextu nezávislého) diskurzu, které navazuje na rozlišení jazykových kódů, a zejména pak charakteristika pedagogických jevů na základě kategorií, které Bernstein nazývá klasifikace (týká se explicitnosti hranic/separace) a rámcováni (distribuce a způsob uplatňování moci zejména $v$ komunikaci). ${ }^{5}$

Klasifikace i rámcování učiva, jeho předávání a hodnocení mohou být silné (viditelné, +), nebo slabé (neviditelné, -). Klasifikace (classification, C) je vlastně míra pevnosti hranic. Typickým prŕkladem je zřejmost či difuznost hranic mezi jednotlivými obory / školními předměty v kurikulu: může jít o kurikulum předmětové $\left(\mathrm{C}_{+}\right)$, anebo o tematickou/integrovanou výuku (C-), ale může jít o hranice vnitrooborové (př́tomnost vztahů mezi různými tématy oboru), hranice času a prostoru ve škole (např. prostory př́stupné žákům vs. vymezené pouze pro učitele), hranice mezi školou a praxí apod. Rámcováni (framing, F) popisuje distribuci moci uvnitř domén vytvořených hranicemi, tj. klasifikací.

\footnotetext{
4 Ostatně stejně tak charakterizuje význam abstraktního vědění i Piaget.

$5 \mathrm{~V}$ české literatuře se framing překládá jako rámování, rámcování i zarámování, popř. se vůbec nepřekládá všechny čtyři verze např. používá Kubáček (2012, s. 19). Zdá se mi, že tezi o diskontinuitě mezi běžným a vědeckým jazykem (viz výše) lépe vyhovuje rámcování. Kromě terminologické neustálenosti se ovšem setkáváme $s$ tím, že v různých teoretických systémech a u jiných autorů se pojetí rámcování od Bernsteinova prístupu méně či více liší.
} 
Rámcování určuje, $k d o$ se (spolu)podílí na rozhodování o výběru učiva (čím se žáci v určitém předmětu či projektu zabývají), na rozhodování o řazení tematických celků, o tempu výuky a kritériích hodnocení apod.

Výsledkem je schéma (tab. 1), které navzdory jisté opacitě Bernsteinových textů - je jasné, výzkumně operacionalizovatelné a prakticky dobře aplikovatelné (jak ukážu v závěrečné části textu). Pravý dolní kvadrant představuje integrovaný kód (C-, F-), můžeme říci na žáka orientovaný př́stup, zatímco levý horní kvadrant odpovídá seriálnímu, na obor zaměřenému kódu (srov. Štech, 2009). Připomeňme, že hranice se týkají např. vymezení školních předmětů, ale také hierarchie ve vztahu školních znalostí / mimoškolních zkušeností apod.

$\mathrm{V}$ tomto textu se z rozsahových důvodů nebudu zabývat dalšími Bernsteinovými idejemi o procesech, které předcházejí dění ve škole a tř́ídě a $\mathrm{v}$ nichž dochází $\mathrm{k}$ produkci a přenosu vědění mezi různými skupinami lidí - těmi, kdo produkují vědění, a těmi, kdo na úrovni celé společnosti provádějí jeho transformaci $z$ vědních oborů do učiva a dále do evaluačních kritérií (Bernstein mluví o rekontextualizaci, srov. Štech, 2009). Místo toho se zaměřím na to, jak výše vyložené myšlenky dále rozvíjí sociální realismus.

\section{SociálNí REALISMUS}

Bernstein přispěl $\mathrm{k}$ tomu, že nejpozději od sedmdesátých let 20 . století měla sociologie enormní vliv na kurikulární uvažování. Př́i tom došlo $\mathrm{k}$ zásadní proměně vnímání školního vzdělávání: zatímco dřive byla škola považována alespoň potenciálně za nástroj řěseni sociálních problémů, nyní stále více autorů označovalo vzdělávací instituce jako príćinu problémů, zejména nerovnosti. Takzvaná nová sociologie vzděláváni $i^{6}$ spatřovala $\mathrm{v}$ akademickém učivu překážku, která brání sociokulturně znevýhodněným žákům ztotožnit se $s$ cíli školy a tím dosáhnout úspěchu. To se týkalo jak vzdělávacích obsahů samých, tak jejich strukturování do tradičních školních př̀edmětů (silná klasifikace, $\mathrm{C}+$ ). V obojím - obsahu i struktuře učiva - tito marxismem i strukturalismem ovlivnění sociologové viděli především výraz mocenských

Tab. 1. Klasifikace a rámcování dle Bernsteina

\begin{tabular}{|c|c|c|c|}
\hline & \multicolumn{2}{|l|}{ Rámcování (kontrola) } \\
\hline & & F+ (silné, viditelné) & F- (slabé, neviditelné) \\
\hline \multirow{2}{*}{$\begin{array}{l}\text { Klasifikace } \\
\text { (hranice) }\end{array}$} & $\begin{array}{l}\text { C+ (silná, } \\
\text { viditelná) }\end{array}$ & $\begin{array}{l}\text { pevnější hranice, učitel } \\
\text { přímo řídí výuku }\end{array}$ & $\begin{array}{l}\text { pevnější hranice, učitel-facilitátor } \\
\text { podporuje žáka }\end{array}$ \\
\hline & $\begin{array}{l}\text { C- (slabá, } \\
\text { neviditelná) }\end{array}$ & $\begin{array}{l}\text { hranice propustné, učitel } \\
\text { př́mo řídí výuku }\end{array}$ & $\begin{array}{l}\text { hranice propustné, učitel-facilitátor } \\
\text { podporuje žáka }\end{array}$ \\
\hline
\end{tabular}

${ }^{6}$ Bernstein k nové sociologii vzdělání bývá někdy řazen. Znalci britské sociologické scény však upozorňují, že sice stál u zrodu tohoto směru, ale sám nebyl jeho součástí, kritizoval ho a vždy šel vlastní cestou (Ball, 2008). 
zájmů elit kapitalistické společnosti. U nás se takto pojatá diskuse o kurikulu pŕíliš nevedla: před rokem 1989 se sociální rozdíly ve vzdělání oficiálně nepřiznávaly a později byl marxismus jako vědecká pozice - na rozdíl od Západu - marginalizován a strukturalismus byl zastíněn novějšími -ismy. Avšak závěry této kritiky byly a jsou u nás přejímány a vůči „tradični“ škole uplatňovány.

Zhruba od počátku nového století však myšlenky nové sociologie vzdělávání zpochybňuje globálně působící skupina autorů hlásících se $\mathrm{k}$ Bernsteinovi. Tito badatelé se označují jako sociální realisté a patří k nim napřr. v Austrálii působící Karl Maton, nedávno zesnulý cambridgeský socio$\log$ Rob Moore, Jihoafričan Johan Muller nebo portugalský tým vedený Anou Moraisovou. Velkou pozornost vzbudilo, když se k sociálnímu realismu přiklonil Michael Young. Tento britský sociolog stejně jako Bernstein působil na londýnském Institute of Education a byl $\mathrm{v}$ počátcích nové sociologie vzdělávání její klíčovou postavou. $\mathrm{V}$ novém tisíciletí však přehodnotil své dřivější kritické názory na tradiční (akademické) kurikulum (např. Young, 2007; Young \& Muller, 2010).

Tradiční obsah školního vzdělávání je podle sociálního realismu skutečně věděním elit, jež mají moc, ale současně je daleko více než jen to. Poznání v něm obsažené přerůstá konkrétní historické okolnosti svého vzniku. $\mathrm{V}$ podstatě $\mathrm{k}$ němu není alternativa. Sociální realisté opustili radikální stanovisko, že dokud bude existovat kapitalistická společnost, není možné dosáhnout spravedlivější školy. Škola je skutečně vưči některým dětem nespravedlivá, lze ale usilovat o dílčí zlepšení a není nutno hned volat po svržení současného rádu (McPhail \& Rata, 2014).

Název sociální realismus vyjadřuje snahu vyhnout se dvěma extrémům: jako realismus odmítá radikální konstruktivismus/ relativismus, podle nichž vědění je vždy jen konvencí určité skupiny lidí a vyjadřuje její zájmy. ${ }^{7}$ Realismus také popírá, že každé vědění je konec konců stejně platné. $\mathrm{Na}$ druhé straně sociální realismus uznává, že poznání a jeho vyjádření ve školním kurikulu je sociálni - historicky podmíněné, zatížené omyly a vyžadující stálou kritiku. Vědění je sociálně produkováno, ale má také schopnost zpětně strukturovat či měnit sociální svět. $\mathrm{V}$ tomto smyslu je reálné, „objektivní", což neznamená absolutní pravdivost, ale schopnost fungovat jako objekt. Vědění vzniká v konkrétní sociální situaci, ale transcenduje ji - má emergentní charakter. Zde sociální realisté navazují na Durkheima a setkávají se s filozofií kritického realismu Roye Bhaskara (1944-2014). Hodí se tu výrok českého filozofa odkazující na Hegelovu dialektiku vývoje, která „nám dovoluje smírit fakt, že jsme něco konstituovali čistě svými jazykovými praktikami, s faktem, že to je skutečné a na nás nezávislé“ (Peregrin, 2012,

\footnotetext{
Můžeme se na tento problém podívat i obráceně. Problém sociální báze akademického učiva neřeší ani to, když tradiční obsahy v kurikulu nahradíme kompetencemi: jakkoli obecně mohou kompetence vypadat, jejich výběr a konkrétní pojetí v kurikulu jsou ve skutečnosti také ovlivněny zájmy určitých politických či ekonomických hráčů (Priestley \& Biesta, 2013; viz též argumentace M. Younga níže).
} 
s. 83). Skutečnost, že poznání je sociálním konstruktem, není zdrojem jeho relativizace, ale naopak prostřednictvím sociální interakce se otevírá cesta $\mathrm{k}$ intersubjektivně platnému vědění. ${ }^{8}$ Že nejde o nějakou umělou, školy se netýkající debatu, naznačuje Knecht (2014a, s. 156-159), který návrat realismu diskutuje $\mathrm{v}$ rámci didaktiky geografie (jeho úvahy však mají daleko obecnější platnost). Ukazuje, jak je obtî̌né řešit konflikt mezi znalostním relativismem (který charakterizoval i východiska české reformy zavádějící rámcové vzdělávací programy) a znalostním absolutismem (o kterém můžeme často mluvit při pohledu do praxe).

Ze sociálního realismu plyne, že obsah kurikula je sociálním konstruktem a proměňuje se v čase, ale měnit jej nelze libovolně. To se týká nejen obsahu, ale i struktury - hranic mezi vzdělávacími oblastmi uvnitř kurikula, rušení nebo vytváření školních předmětů apod. Právě tak nelze libovolně setřít rozdíl mezi školním a každodenním poznáním. V tomto světle se mi jako zásadně problematická jeví klíčová teze RVP ZV, podle níž má základní škola „poskytnout spolehlivý základ všeobecného vzdělání orientovaného zejména na situace blizké životu a na praktické jednánı" (důraz DD), pokud by implikovala nadřazenost praxe teorii nebo byla chápána jako návod pro výběr vzdělávacího obsahu. Spornost takové koncepce vyplývájižz toho, že pro polovinu žáků je dnes základní vzdělávání př́ípravou nejen na vyšší sekundární, ale také na terciární vzdělávání.

\section{DVA TYPY KURIKULA}

Můžeme tedy rozlišit dvě epistemologické pozice: (1) vědění je vždy vázané na svého nositele, vyjadřuje jeho potřeby a zájmy, přizpůsobuje se mu, anebo (2) vědění je do značné míry nezávislé na tom, kdo ho vytvárí nebo se mu učí, a jedinec se mu musí přizpůsobit. $V$ prvním př́padě je proto třeba vědění a jeho předávání organizovat podle potřeb konkrétního nositele (jeho praxe), v druhém prrípadě je vědění strukturováno svou vlastní logikou. Vědění se řídí bud' kritérii vnějšími (praxe, žák), nebo vnitřními (obor). V následující části textu víc rozvedeme, jak tyto dvě různé pozice vedou $\mathrm{k}$ různým typům kurikula. Předtím však ještě poukážeme na související rozlišení vědění jako relativně stálé struktury, anebo dynamického procesu (McPhail \& Rata, 2014).

$\mathrm{V}$ naší reformě, která byla zahájena v minulé dekádě, asi nehrála zásadní roli kritika dosavadního obsahu školního vzdělávání z marxistických, postkoloniálních, feministických a podobných pozic (na rozdíl od některých západních zemí). Daleko častěji zazníval argument, že dynamika sociálních proměn je tak velká, že škola nemá žáky vybavovat tradičními znalostmi, ale především obecnými „klíčovými“ kompetencemi, tvořivostí apod. Vědění je dnes

\footnotetext{
8 K realismu (v Popperově pojetí) se hlásí i naši významní didaktici Hejný a Kư̌ina (2001). Domnívám se však, že je potřeba rozlišovat, kdy mluví o epistemologii a kdy o didaktice. Uvedení autoři se hlásí k epistemologickému realismu a umírněnému didaktickému konstruktivismu. Zajímavá je v této souvislosti argumentace Kvasze (2016): i když Hejný jde cestou didaktické konstrukce vědění, respektuje závaznost jeho pevného rámce.
} 
prý tak rychle vytvářeno, že nikdo nemůže zvládnout vše potřebné, a současně učivo tak rychle zastarává, že jediné, co má prý smysl, je schopnost pracovat $s$ věděním, $s$ informacemi. Znalost je tedy dovednost práce $s$ informacemi, je to vlastně proces. Jak upozorňuje např. Biesta (Priestley \& Biesta, 2013), učení už není prostredkem k získání znalosti, ale stává se samo cílem. ${ }^{9}$ Jde o součást dlouhodobé proměny pojetí vzdělanosti: od ideálu člověka, který má ve své mysli určitý strukturovaný obraz světa, $\mathrm{k}$ jedinci, který umí ve světě efektivně fungovat (MacKnight, 2011).

Proti tomu stojí názor realistů, že vědění je tvořeno na nás nezávislými soustavami významů, je to tedy relativně stálá struktu$r a$ poznatků. Podstatné je, že tyto poznatky jsou organizovány v hranicích jednotlivých oborů prostřednictvím pojmů $s$ rostoucí mírou abstrakce. Vedou k porozumění, které se často dostává do rozporu s praktickými zkušenostmi: teoretické vědění je kontraintuitivní. Kromě uvedených inspirací Durkheimem a Bernsteinem je zde často připomínán L. S. Vygotskij - jeho důraz na rozdíl mezi spontánními a vědeckými pojmy a přesvědčení o významu vědeckých pojmů pro rozvoj myšlení dítěte. Přitom pojmová struktura jednotlivých oborů se zásadněji mění jen velmi zrŕdka. I paradigmatické změny při tom často zachovávají předchozí obraz světa jako speciální prípad či alespoň didakticky vhodný předstupeň nové teorie.
Dnes se zdá, že se ve vzdělávací politice prosazují kurikula ${ }^{10}$ vycházející z prvního pojetí: vědění je chápáno jako proces (dovednost), učivo se strukturuje podle potřeb či zájmů žáka, socializační role školy se staví nad kvalifikační. V zahraniční literatuře se v poslední době často mluví o zaměření vzdělávání na „dovednosti pro 21. století". Budu proto mluvit o futuristických kurikulech, která se chtějí rozejít s tradicí a odvolávají se na budoucí podmínky a potřeby života jedince i společnosti. Můžeme sem zařadit např. naše rámcové vzdělávací programy nebo skotské „Kurikulum pro excelenci“. Taková kurikula často vycházejí žákům vstřríc (vstřícné pojetí), učivo se organizuje podle jejich zájmů a zkušeností, $\mathrm{v}$ každé škole či dokonce tř́idě specificky prostřednictvím školních vzdělávacích programů, témat, projektů apod.

V sociálních realistech však tento př́stup vyvolává obavy, nebot́ ve skutečnosti část mladých lidí i nadále má (díky svému rodinnému zázemí, existenci elitních škol apod.) př́stup ke specializovaným oborovým znalostem a tedy $\mathrm{i} \mathrm{k}$ dobře placeným profesím, které je vyžadují. $\mathrm{Na}$ druhou stranu absolventi běžných škol vybavení jen „klíčovými“, ve skutečnosti však nespecifickými dovednostmi, jsou odsouzeni $\mathrm{k}$ jednoduché nekvalifikované, a tedy špatně placené práci (Young, 2008). Zvládnutí tradičních oborů (at' je to matematika, nebo hra na housle) je těžké, trvá dlouho, a vyžaduje proto velké úsilí a motivaci,

\footnotetext{
$\mathrm{Z}$ tohoto hlediska může být špatně pochopen i důraz na učení/vyučování jako nejdůležitější kritérium kvality školy; pokud by se proces stával důležitějším než jeho výsledek.

${ }^{10}$ Měl bych zde asi vhodněji mluvit o rámcových či koncepčních dokumentech, nebot́ pojem kurikulum je př́liš široký. Mám tedy na mysli projekty podobné naším rámcovým vzdělávacím programům.
} 
jíž se skutečně mnoha dětem nedostává. Stát naproti tomu chce umožnit přístup $\mathrm{k}$ vyššímu vzdělávání stále většímu podílu populačního ročníku, aniž by vynakládal dostatečné náklady na nezbytná pedagogická i sociální opatření umožňující většímu podílu mladých lidí zvládnout náročné požadavky na znalosti tradičně spojované s představou maturity či vysokoškolského studia. Obrat k futuristickému kurikulu, které jako naše RVP staví do popředí především „měkké dovednosti“, tak jen posílí rozdělení společnosti na ty, kdo získají na trhu práce poptávané profesní znalosti, a ty, kdo je mít nebudou. Proto sociální realisté požadují pro všechny kurikulum respektující povahu potencujícího vědění, které je teoretické/abstraktní, oborově členěné. Ve vzdělání je potřeba nejdříve respektovat hranice (mezi teorií a praxí, mezi obory navzájem, mezi učitelem a žákem), aby je bylo později možno překonat (Young \& Muller, 2010).

Přesto se nemohu ubránit určité pochybnosti: Sociálními realisty kritizovaná futuristická kurikula se v poslední době stala východiskem více různých vzdělávacích reforem a existují tak s nimi určité zkušenosti (včetně jejich problémů či selhání). ${ }^{11}$ Naproti tomu „realistická“ kurikula zůstávají převážně v rovině teoretických návrhů (jak tvrdí McPhail \& Rata,
2016), nejsou tedy podložena empirickou evidencí1 $^{12}$ a nedostala př́ležitost osvědčit se ve škole.

Je to ale pravda? Nabízí opravdu sociální realismus něco jiného než návrat $\mathrm{k}$ tradičnímu modelu vzdělávání? Např́íklad Tyack a Cuban (1995) se domnívají, že akademický/scientistní př́stup je $\mathrm{v}$ historii školství dominantní a období na žáka zaměřené výuky jsou naopak spíše výjimkou. Zatím neznáme ani analýzu vztahu sociálního realismu ke kurikulárnímu hnutí šedesátých let minulého století, $\mathrm{k}$ vzdělávacím standardům (Knecht, 2014b) a k dalším reformám, které rovněž vycházely z obdobných myšlenek a $\mathrm{z}$ nichž u nás nejvíc známe československé „nové pojeti'“. ${ }^{13}$ Podívejme se na tuto otázku blíže.

\subsection{Nové pojetí jako ideální případ sekvenčního kurikula?}

\section{Reformy známé jako kurikulárni hnutí} byly reakcí na progresivní, popř. pedocentrické proudy zejména v americkém školství (v Sovětském svazu byly $\mathrm{v}$ dobové terminologii "pedologické úchylky“ potlačeny již před druhou světovou válkou). Jejich sociálním kontextem byla studená válka, $\mathrm{k}$ intelektuálním zdrojům patří strukturalismus, kognitivní a sociokognitivní psychologie. Reformy se týkaly zejména

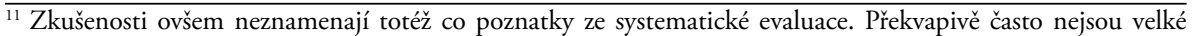
„futuristické“ reformy provázeny odpovídajícími výzkumy jejich průběhu a dopadů.

${ }^{12}$ Domnívám se totiž, že je nutno odlišovat výzkumnou evidenci, kterou poskytují psychologické výzkumy a která se týká učení v laboratorních podmínkách na omezených úsecích učiva, od evidence o fungování celých kurikul v podmínkách větších souborů škol či celých školských systémů.

${ }^{13}$ Pozoruhodnou výjimkou je Youngova poznámka o názoru Petera Gavory, že snaha zavést Vygotského autoritou podložené Zankovovy principy „mezi lety 1970 a 1980 málem zmrzačila československé primární školstvi“ (Young, 2007, s. 223).
} 
vyučování přírodních věd a matematiky (Helgeson, Blosser \& Howe, 1977), i když klíčový protagonista J. Bruner se zabýval i reformou výuky společenských věd. Za základní rysy kurikulárního hnutí se považuje (1) důraz na strukturu poznatků vědních disciplín, a to $\mathrm{v}$ jejich náročné, akademické, nikoli aplikační podobě, a (2) důraz na procesuální stránku oborů (vědecké postupy), kterým měla odpovídat výuka akcentující učení objevováním, laboratorní činnost žáků v hodinách apod.

V Československu se kurikulární reforma (označovaná jako nové pojetí či nová koncepce vzdělávací soustavy) prripravovala od šedesátých let minulého století. Čeští pedagogové $\mathrm{v}$ době zavádění nového pojetí řešili obdobné problémy, s nimiž se chtějí vypořádat současní zastánci kompetenčních futuristických kurikul, ale dospěli $\mathrm{v}$ podstatě $\mathrm{k}$ protikladnému závěru. $\mathrm{Na}$ druhou stranu byla argumentace ,nového pojetí" blízko pozici sociálního realismu (a ukazuje to pravděpodobně na společnou inspiraci Vygotským):

„V době zrychleného tempa změn ve výrobní i jiné praxi může vzdělání těžko zachytit aktuální stav. Pokusy o stálou aktualizaci vzdělání ve smyslu nejnovějších změn praxe mohou přinést jen částečné řešení, protože vzdělání nepřipravuje jen pro aktuální praxi, ale produkuje i nositele budoucích změn. Proto se těžišš vzdělání musí přesouvat $\mathrm{k}$ teoretickým základìm praxe. I když pro každou práci jsou praktické zkušenosti nezbytné, je znalost teorie cennějš́s, samožrejmě teorie opřené o praxi. Podstata vztahu teorie a praxe se liší od starých názorů tím, že nejde na prvním místě o proporci teoretické a praktické přípravy, ale o jejich nutné spojení, o to, aby se vzájemně podporovaly." (Pařízek, 1984, s. 37-38, zdůraznil DD)

Rozsáhlé experimentální ověřování nového pojetí probíhalo od počátku sedmdesátých let, ve školním roce 1976 až 1977 vstoupila reforma do všech prvních ročníků základní školy a v osmdesátých letech do středních škol. Tato reforma nepochybně zásadně ovlivnila organizaci, obsah i metody vzdělávání $\mathrm{v}$ českých zemích a na Slovensku před rokem 1989 a lze se domnívat, že její vliv ještě přetrvává. $\mathrm{Na}$ druhou stranu právě proti tomuto dědictví se $\mathrm{v}$ posledním čtvrtstoletí vymezovaly mnohé snahy o změnu českého školství. Také zahraniční pokusy o modernizaci vyučování $\mathrm{v}$ duchu kurikulárního hnutí bývají často považovány za neúspěšné. I J. Průcha (který tam, kde si to školství v období socialismu zaslouží, vystupuje na jeho obranu) řadí scientistní koncepci socialistické školy jasně mezi negativa:

„Po celou dobu své existence za socialismu bylo učivo nadměrně syceno teoriemi jednotlivých věd a vědeckých disciplín, což vedlo $k$ přetízenosti učiva odbornými pojmy a termíny, k encyklopedičnosti a velké detailnosti učiva - zkrátka obsah vzdělávání nebyl přizpůsoben kognitivním schopnostem žáků př́slušného věku." (Průcha, 2015, s. 30-31)

Tato slabina reformy byla podle Průchy natolik zjevná, že se jí ve své době zabývali nejen pedagogičtí odborníci, ale i stranické orgány, přesto $\mathrm{k}$ nápravě docházelo jen pomalu a nedostatečně. Je proto neblahé, že nové pojetí stojí stranou pozornosti 
výzkumníků a chybí jeho důkladné zhodnocení. Je totiž otázkou, zda bylo opravdu zcela mylné, nebo naopak $\mathrm{v}$ něčem předběhlo svou dobu a předjímalo agendu sociálního realismu.

Socialistická škola se vyznačovala nezměrným optimismem, pokud šlo o možnost všech žáků zvládnout i náročné učivo, nebot si neprripouštěla, že by v komunistické společnosti mohly přetrvávat nerovnosti podmíněné jejich sociálním postavením. Ty, kdo neuspěli, vyřazovala $z$ hlavního vzdělávacího proudu do speciálních škol, protože jejich neúspěch ideologie nedovolovala připsat vnějším (sociokulturním) faktorům. Neúspěch musel být připsán vnitřním faktorům na straně jedince - snížené inteligenci. Do určité míry paradoxně mohla pojmout na vy̌šši sekundární úrovni všeobecné vzdělání tradičně akademicky/scientistně, nebot́ poskytovala prístup $\mathrm{k}$ akademickému kurikulu jen zlomku středoškoláků přijatých ke studiu na gymnáziích nebo některých elitních průmyslovkách. ${ }^{14}$ Dnes si ovšem vzdělávací systémy kladou za cíl poskytnout úplné střední vzdělání širokému spektru žáků, kteří by měli být schopni pokračovat do terciárního stupně (Dvořák, 2016). Nabízí tady sociální realismus nějaké řešení?

\subsection{Praktické ohledy: jednotná škola a akademická připravenost}

I když je vědění produktem společnosti, není jen odrazem třídních rozdílů nebo podobných sociálních nerovností. Přesto sociologie musí dále kritizovat sociálně podmíněné rozdíly $\mathrm{v}$ distribuci vědění, věrna svému ústřednímu úkolu zkoumat, jak se liší situace mocných a bez-mocných. Sociální realisté nepopírají odcizení žáků zejména dětí ze znevýhodněných prostředí - od školního vzdělání ani to, že tradiční kurikulum odráží vědění těch, „kdo mají moc “. ${ }^{15}$ Přesto, anebo právě proto jde dle sociálního realismu o obsahy důležité pro každého. Jsou chápány jako dekontextualizované, avšak potencující neboli „mocné“ vědění ${ }^{16}$ umožňující přesáhnout omezenost člověka jeho dosavadním horizontem (Štech, 2004, 2009). Odcizení žáků od dnešního školního učiva podle sociálního realismu tedy nelze řešit tím, že budeme hledat nějaké jiné, žákům bližší učivo nebo diferencovat vzdělávací dráhy; naopak je úkolem každé generace učitelů znovu hledat cesty, po nichž lze pokud možno všechny žáky $\mathrm{k}$ tomuto podstatnému, „mocnému“ vědění přivádět. Ve zbyt-

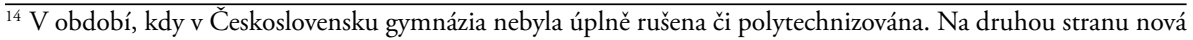
koncepce vytvořila nový typ školy - odborné učiliště zakončené maturitou.

15 Jde zřejmě především o problém (jednotné) sekundární školy, nebot historicky zdrojem jejího kurikula bylo dřivější elitní víceleté gymnázium. Stejně jako se za vesměs neúspěšné považují snahy o modernizaci vyučování, tak očekávání nenaplnily ani strukturální reformy, které směrovaly k jednotné sekundární škole (Gesamtschule v Německu, college ve Francii, komprehensivní high school v USA), často akademické, resp. kladoucí si za cíl pro terciární studium potenciálně připravit celou populaci (Lee \& Ready, 2009; Váňová, 2016). Stejně tak jen střídavé úspěchy vykazují nové modely škol v oblastech $s$ vy̌šsím podílem znevýhodněných žáků (charter schools, akademie v Anglii apod.), viz též Power (2008).

${ }^{16}$ Překlad „potencující vědění je podle Knechta (2014a) již zavedený, avšak stírá významovou hru vědění mocných / mocné vědění.
} 
ku textu se podíváme, jak sociální realismus řeší tento problém.

Především řekněme, že hledanou cestou nemusí být ,inovativni“ metody, nebot právě pro žáky, kterým chceme nejvíce pomoci, nemusí být výhodné úplné opuštění tradiční pedagogiky (napřr. nahrazení transmisivního vyučování konstruktivistickými metodami práce). Tyto metody kladou na žáky (a jejich rodiče) totiž často ještě větší nároky než dosavadní pojetí školní výuky. ${ }^{17}$ Sociální realismus proto upozorňuje, že "nová pedagogika“" ve skutečnosti může být $\mathrm{v}$ zájmu relativně úzkých vrstev nové střední třídy. Původně se totiž v optice sociálního realismu zdálo, že koncepty klasifikace a rámcování vedou $\mathrm{k}$ jednoduché dichotomii: nové, progresivní pedagogické př́stupy s „neviditelnými“ (C-, F-) hranicemi a pravidly jsou pro znevýhodněné skupiny ještě hůře srozumitelné než dosavadní škola (Moore, 2006). To by vedlo $k$ závěru, že přinejmenším pro děti $\mathrm{z}$ nepodnětného prostředí jsou obecně vhodnější tradiční pedagogické prístupy. Takový závěr se ovšem předem zdál jako „politicky nekorektni“ a neprůchodný, zejména $\mathrm{v}$ atmosfére nakloněné všem možným alternativním postupům. Navíc další výzkum ukázal, že je uvedený závěr prŕliš zjednodušující a je zde potřeba diferencovanější přístup, který představím v následujících odstavcích.

\subsection{Smíšený pedagogický přístup}

Řadu empirických výzkumů založených na Bernsteinových analytických konceptech vykonala portugalská skupina ESSA (Estudos Sociológicos da Sala de Aula, Sociologická studia třídy). ESSA se nejvíce zabývala výukou přírodovědných předmětů od předškolního po terciární vzdělávání (např. Calado, Neves \& Morais, 2013; Morais \& Neves, 2011), jejich přístup byl aplikován $\mathrm{v}$ jiných podmínkách (Jižní Afrika) např. na výuku znevýhodněných žáků $\mathrm{v}$ matematice. Pro analýzy výuky byla vytvořena řada nástrojů, které mají podobu čtyřstupňových škál hodnotících různé aspekty z hlediska síly/viditelnosti klasifikace a rámcování (tab. 2). Ty umožnily hledat optimální kombinace sledovaných aspektů $\mathrm{z}$ hlediska maximalizace učení všech a zvlášt znevýhodněných žáků.

Tyto výzkumy ukazují, že jako nejvhodnější se jeví smiśsený pedagogický prístup, jehož nejdůležitější aspekty jsou silnél viditelné rámcování $(\mathrm{F}+)$ z hlediska výběru kurikulárního obsahu a evaluačních kritérií a slabé rámcování $(\mathrm{F}-)$ z hlediska tempa (pacing) a hlavně interpersonální interakce žák-učitel. V tomto vztahu tedy jsou vzdělávací cíle a obsahy žákům určovány zvenčí (přinejmenším na makroúrovni) a učitel

\footnotetext{
${ }^{17}$ Inovativní metody často kladou větší nároky i na znalosti učitele. Na tom může také ztroskotat snaha zavést inovativní postupy ve školách $s$ velkou kumulací znevýhodněných žáků. Naše výzkumy (Dvořák, Starý \& Urbánek, 2015) naznačily, že nejlepší učitele dnes nasávají soukromé školy vzdělávající děti ekonomických a kulturních elit. Hoadley (dle Muller \& Gamble, 2010) navíc zjistil, že učitelé pocházející z nižších sociálních vrstev vnášejí do třídy konkrétně a kontextově orientovanou komunikaci, která nepomáhá žákům v osvojení abstraktněji zaměřených způsobů poznávání. To by mohlo také částečně vysvětlovat rozporuplné výsledky působení pedagogických asistentů.
} 
Tab. 2. Př́klad škály pro hodnocení pozorování výuky: poskytování zpětné vazby (zdroj: Morais \& Neves, 2011)

\begin{tabular}{|l|l|}
\hline $\begin{array}{l}\text { Rámcování } \\
\text { (kontrola) }\end{array}$ & Deskriptory \\
\hline Silné $(\mathbf{F + +})$ & $\begin{array}{l}\text { Učitel systematicky, jasně a konkrétně ukazuje, co a proč je považováno za } \\
\text { správné/nesprávné. }\end{array}$ \\
\hline Středně silné $(\mathbf{F}+)$ & Učitel obecně hodnotí, co je a není považováno za správné. \\
\hline Středně slabé (F-) & Učitel označuje chyby, ale neopravuje je. \\
\hline Slabé $(\mathbf{F}--)$ & $\begin{array}{l}\text { Učitel prijímá všechny žákovy odpovědi, jeho vstupy/otázky směřují pouze } \\
\text { k jejich dodatečnému upřesnění či vyjasnění. }\end{array}$ \\
\hline
\end{tabular}

explicitně stanovuje kritéria hodnocení, ale zároveň je žákům zdůvodňuje. Současně je žádoucí oslabení hierarchických vztahů mezi učitelem a žákem, otevřený, přátelský vztah mezi dospělými a žáky i mezi žáky navzájem. Žák může ovlivňovat tempo práce nebo dostat čas navíc. Ve dvou hlediscích se tedy „ideální model podobá "tradiční" direktivní škole a dvěma momenty se víc blíží progresivní pedagogice (Barrett \& Moore, 2015; Muller \& Gamble, 2010). Kromě toho ovšem výzkumy přírodovědné výuky zdůrazňují, že učitel musí mít hlubokou znalost oboru, aby udržel výuku na adekvátně konceptuálně náročné úrovni - „absenci oborových znalostí nelze nahradit sebelepší metodikou“ (Morais \& Neves, 2011, s. 193).

Doporučení pro smíšený př́stup se týkají i dalších oblastí, jako napřr. oslabení klasifikace prostorového členění školy (propustnost hranic mezi místy určenými žákům a učitelům) a rovněž posílení vnitropředmětových vztahů (C-, to znamená, že se ve výuce po- ukazuje na souvislosti s jinými tématy v rámci daného vzdělávacího oboru či oblasti). Pro vztah školy a praxe smíšená pedagogika doporučuje, aby učitel odkazoval k mimoškolním/praktickým situacím (C-), ale důsledně je vysvětloval teoretickým aparátem školního předmětu. ${ }^{18}$

Tato zjištění jsou $\mathrm{v}$ dobré shodě $s$ tím, co víme ze zahraničních i domácích výzkumů o důležitosti náročné oborové pojmové struktury učiva (Janík et al., 2013; Slavík \& Janík, 2012) a př́ležitostí k učení (Knecht, 2014b), klíčové roli podrobné zpětné vazby / formativního hodnocení (Starý et al., 2016) nebo o funkční cirkulaci moci mezi učitelem a žákem a jejich vzájemném respektu (Šedová et al., 2016). Model smíšené didaktiky je přehledným způsobem spojuje, vnáší do nich sociologické hledisko a elegantně kombinuje tradiční a progresivní př́stupy. Než bude zřejmé, zda skutečně představuje cestu $\mathrm{k}$ obsahově kvalitní výuce a současně úspěšnému učení co nejširš̌i skupiny žáků, jsou však nepochybně potřebné další výzkumy.

\footnotetext{
${ }^{18}$ Domnívám se, že z hlediska této analýzy v „nové koncepci“ (odstavec 3.1) pojmově náročný obsah nebyl vyvážen dostatečnou pružností při implementaci obecně a v oblasti tempa výuky, a péćí o vztah učitel-žák zvláště. Navíc okolnosti jako autoritativní politický režim a vrchol demografické vlny s přeplněnými tř́idami jistě situaci škol neusnadňovaly.
} 


\section{SHRNUTí}

Pokusů zvýšit obsahovou kvalitu výuky chápanou zejména jako její konceptuální náročnost proběhlo $\mathrm{v}$ posledních dekádách několik. Jejich kritickým místem se často ukazuje být školní neúspěšnost žáků ze znevýhodněného prostředí. Komplexní analýzu tohoto jevu provedl B. Bernstein, na kterého navazuje proud označovaný jako sociální realismus. Zdůrazňuje nezastupitelnost tradičního oborově členěného a na teoretickém vědění založeného akademického kurikula a potřebu předávat ho co nejširší skupině žáků. Současně hledá, jak účinně zprostředkovat takové kurikulum žákům ze znevýhodněného prostředí. Sociální realismus nabízí vizi kurikula a vyučování, které se vyhýbá dvěma extrémům: jak konzervativnímu návratu $\mathrm{k}$ znalostnímu absolutismu (až memorování) a tradiční hierarchické škole, ale i nekritickému odvržení tradičního oborového vědění ve jménu futuristických vizí, znalostního relativismu a alternativ za každou cenu (Young \& Muller, 2010). Nezaměňuje žádoucí cílový stav plně autonomního dospělého s př́ítomnou úrovní předpokladů žáka-začátečníka, respektuje hranice jako podmínky růstu (Štech, 2016). V empirických výzkumech se ukazuje jako nadějný smíšený pedagogický model, který respektuje pojmovou strukturu jednotlivých oborů a závaznost jejich hodnotících kritérií, a ve výuce kombinuje prvky transmisivního a progresivního přístupu.

\section{Literatura}

Ball, S. J. (2008). Some sociologies of education: a history of problems and places, and segments and gazes. The Sociological Review, 56(4), 650-669.

Barrett, B., \& Moore, R. (2015). Changing from within: Basil Bernstein, teacher education and social justice. In P. Vitale \& B. Exley, Pedagogic rights and democratic education. Bernsteinian explorations of curriculum, pedagogy and assessment. Abingdon: Routledge.

Bernstein, B. (1990/2003). Class, codes and control. Volume IV. The structuring of pedagogic discourse. Abingdon: Routledge.

Bernstein, B. (1996/2000). Pedagogy, symbolic control and identity: Theory, research, critique. Oxford: Rowman and Litlefield.

Bulle, N. (2008). Sociology and education: issues in sociology of education. Bern: Peter Lang.

Calado, S., Neves, I. P., \& Morais, A. M. (2013). Conceptual demand of science curricula: a study at the middle school level. Pedagogies: An International Journal, 8(3), 255-277.

Durkheim, É. (1893/2004). Společenská délba práce. Brno: CDK 2004.

Durkheim, É. (1912/2002). Elementárni formy náboženského života. Praha: Oikoymenh.

Dvořák, D. (2015). Proměny kurikulárního diskurzu: o aktérech, standardech a ledních medvědech. In D. Greger (Ed.), Srovnávací pedagogika: Promèny a výzvy (s. 101-117). Praha: Univerzita Karlova.

Dvořák, D. (2016). Akademické cíle základního vzdělání v 21. století. In M. Strouhal \& S. Štech (Eds.), Vzděláni a dnešek (s. 147-163). Praha: Karolinum. 
Dvořák, D., Starý, K., \& Urbánek, P. (2015). Škola v globálni době: Promèny pěti českých základnich škol. Praha: Karolinum.

Hejný, M., \& Kuřina, F. (2001). Ditè, škola a matematika. Praha: Portál.

Helgeson, S. L., Blosser, P. E., \& Howe, R. W. (1977). The status of pre-college science, mathematics and social science education 1955-1975. Columbus (OH): Ohio State University.

Hubík, S. (1999). Sociologie vědění. Praha: Sociologické nakladatelství.

Janík, T., \& Slavík, J. (2009). Obory ve škole a jejich enkulturační funkce. Pedagogická orientace, $19(2), 5-21$.

Janík, T., Slavík, J., Mužík, V., Trna, J., Janko, T., Lokajićková, V., ... Zlatníček. P. (2013). Kvalita (ve) vzdělávání: obsahově zaměřný přístup ke zkoumání a zlepšování výuky. Brno: Masarykova univerzita.

Kadlec, T. (2012). Social realism, knowledge and the sociology of education: Coalitions of the mind. [Recenze stejnojmenné knihy, autoři K. Maton a R. Moore.] Orbis Scholae, 6(1), 139-141.

Knecht, P. (2014a). Príležitosti $k$ rozvijeni kompetence $k$ řešeni problémů v učebnicich a ve výuce zemépisu. Brno: Masarykova univerzita.

Knecht, P. (2014b). Př́ležitosti k učení: odlišná/různá pojetí konceptu a jeho výzkumné využití. Pedagogická orientace, 24(2), 163-184.

Kubáček, J. (2012). Slovnik politického managementu a volebniho marketingu. Praha: Grada.

Lee, V. E., \& Ready, D. D. (2009). U.S. high school curriculum: Three phases of contemporary research and reform. Future Child, 19(1),135-156.

MacKnight, V. (2011). Ideal knowing: Logics of knowledge in primary school. British Journal of Sociology of Education, 32(5), 717-728.

Maton, K., \& Moore, R. (Eds.). (2009). Social realism, knowledge and the sociology of education: Coalitions of the mind. A\&C Black.

McPhail, G., \& Rata, E. (2016). Comparing curriculum types: ,Powerful knowledge' and ,21st century learning. New Zealand Journal of Educational Studies, 51(1), 53-68.

Moore, R. (2006). The structure of pedagogic discourse. In H. Lauder, P. Brown, J.-A. Dillabough \& A. H. Halsey (Eds.), Education, globalization, and social change (s. 742-759). Oxford: OUP.

Morais, A. M. \& Neves, I. P. (2011). Educational texts and contexts that work: Discussing the optimization of a model of pedagogic practice. In D. Frandji \& P. Vitale (Eds.), Knowledge, pedagogy \& society: International perspectives on Basil Bernstein's sociology of education (kap. 12). London: Routledge.

Muller, J. \& Gamble, J. (2010). Curriculum and structuralist sociology: The theory of codes and knowledge structures. In P. Peterson, E. Baker \& B. McGaw (Eds.), International encyclopedia of education (vol. 1, s. 505-509). Oxford: Elsevier.

Pařízek, V. (1984). Kobsahu vzdèláni a jeho soudobým promènám. Praha: SPN.

Pausigere, P. (2016). On Bernstein's sociology of pedagogy and how it can inform the pedagogic realisation of poor and working-class children in South African primary maths education. Educational Research for Social Change, 5(1), 41-53. 
Peregrin, J. (2012). Spory o realismus, Hegel a jazyk(y) matematiky. Organon F, 19(1), 66-83. Perry, L. B., \& Lamb, S. (2016). Curricular differentiation and stratification in Australia. Orbis scholae, 10(3), 27-47.

Power, S. (2008). How should we respond to the continuing failure of compensatory education? Orbis scholae, 2(2), 19-38.

Priestley, M., \& Biesta, G. (Eds.). (2013). Reinventing the curriculum: New trends in curriculum policy and practice. A\&C Black.

Průcha, J. (2015). Česká vzdělanost. Multidisciplinární pobled na fenomén národní kultury. Praha: Wolters Kluwer.

Rata, E. (2016). A pedagogy of conceptual progression and the case for academic knowledge. British Educational Research Journal, 42(1), 168-184.

Rizvi, F., \& Lingard, B. (2009). Globalizing education policy. Routledge.

Sadovnik, A. R. (2001). Basil Bernstein. Prospects, 29(4), 687-703.

Slavík, J., \& Janík, T. (2012). Kvalita výuky: obsahově zaměřený př́stup ke studiu procesů vyučování a učení. Pedagogika, 62(3), 262-286.

Starý, K., Laufková, V., Stará, J., Novotná, K., Štastný, V., \& Svobodová, Z. (2016). Formativní hodnoceni ve výuce. Praha: Portál.

Šed’ová, K., Švaříček, R., Sedláček, M., \& Šalamounová, Z. (2016). Jak se učitelé uči. Cestou profesniho rozvoje k dialogickému vyučováni. Brno: Masarykova univerzita.

Štech, S. (2004). Psychologické pobledy na školu - rozumime školni socializaci? Vystoupení na konferenci Psychologické dny, Olomouc.

Štech, S. (2009). Zřetel k učivu a problém dvou modelů kurikula. Pedagogika, 59(2), 105-115.

Štech, S. (2013). Co přinesl „obrat k dítěti“ a co naopak skryl? Pedagogika, 66(1), 73-82.

Štech, S. (2013). Když je kurikulární reforma evidence-less. Pedagogická orientace, 23(5), 615-633.

Tyack, D., \& Cuban, L. (1995). Tinkering toward utopia: A century of public school reform. Cambridge: Harvard University Press.

Váňová, M. (2016). Francouzská nižší sekundární škola - collège. Lifelong Learning - celoživotni vzdèlávání, 6(2), 8-22.

Young, M. (2007). Bringing knowledge back in: From social constructivism to social realism in the sociology of education. Routledge.

Young, M. (2008). From constructivism to realism in the sociology of the curriculum. Review of Research in Education, 32(1), 1-28.

Young, M., \& Muller, J. (2010). Three educational scenarios for the future: Lessons from the sociology of knowledge. European Journal of Education, 45(1), 11-27.

RNDr. Dominik Dvorák, Ph.D.

Univerzita Karlova, Pedagogická fakulta, Ústav vízkumu a rozvoje vzdèlávání;

e-mail:dominik.dvorak@pedf.cuni.cz 
DVǑ̌́A, D. Educational Content: Do Bernstein's theory and social realism show us a way out of crisis?

This theoretical study highlights two circumstances that are limiting the quality of educational content: the absence of a theory of knowledge and problems with the communication of a conceptually demanding curriculum to some pupils from socioculturally disadvantaged backgrounds. The late sociological work of Basil Bernstein may be helpful in overcoming both problems, and so this article outlines some of his ideas, which are less well known in the country. It also shows how these concepts are the premises of what is known as social realism as understood by M. Young and a group of Bernstein's pupils. It describes two models of curriculum that are grounded in the notion of knowledge as system versus process. Ultimately a mixed model of teaching is presented, combining elements of traditional and progressive pedagogic theory and representing a promising way forward as regards communicating conceptually challenging curricula to a wide spectrum of pupils.

Keywords: curriculum, educational content, sociology of education, social realism. 